\title{
UJI POTENSI DAYA HAMBAT EKSTRAK METANOL BIJI JINTAN HITAM (Nigella Sativa L.) TERHADAP BAKTERI STREPTOCOCCUS
}

\author{
Inhibitory Potential Test of Black Cumin Seeds (Nigella Savita L.) Methanol Exstract \\ Against Streptoccus Bacteria
}

\author{
Guntur Satrio $\mathbf{P}^{1^{*}}$ \\ Nurul Chusna ${ }^{2}$ \\ Muhammad Priyadi ${ }^{3}$ \\ *1,2,3Dosen Pengajar Program \\ Studi D-III Farmasi, Fakultas \\ Ilmu Kesehatan, Universitas \\ Muhammadiyah Palangkaraya, \\ Palangka Raya, Kalimantan \\ Tengah \\ *email:
}

Kata Kunci:

Daya Hambat

Ekstrak methanol jinten Hitam

Streptococcus

\section{Keywords:}

Inhibition

Black cumin methanol extract

Streptococcus

\begin{abstract}
Abstrak
Salah satu tanaman yang sering dimanfaatkan sebagai tanaman obat adalah Habbatussauda, habbatussauda' merupakan tanaman obat yang dikenal di Indonesia dengan nama Jintan hitam. Biji dan minyak esensial jintan hitam (Nigella sativa L.) telah banyak digunakan dalam pengobatan tradisional. Banyak penelitian yang telah membuktikan efek ekstrak Nigella sativa. Dalam berbagai penelitian, minyak biji jintan hitam menunjukkan khasiat sebagai anti kanker, anti radikal bebas dan immunomodulator, analgesik, antimikroba, anti inflamasi, spasmolitik, bronkhodilator, hepatoprotektif, dan anti hipertensi Analisis kimia lanjutan menemukan bahwa habbatussaudaa mengandung karoten yang diubah menjadi vitamin $A$ oleh hati. Tujuan penelitian ini adalah untuk mengetahui potensi daya hambat ekstrak methanol biji jintan hitam (Nigella Sativa L.)Terhadap Bakteri Streptococcus. Penelitian ini menggunakan pendekatan kuantitatif dengan metode ekperimental. Penelitian ini dilakukan di laboratorium Farmakognosi dan Mikrobiologi Fakultas IImu Kesehatan Universitas Muhammadiyah Palangkaraya. Sampel yang digunakan adalah sampel dari bahan tanaman yaitu Biji Jintan Hitam (Nigella sativa $\mathrm{L}$ ) yang telah dikeringkan dan diserbukkan dan kemudian diekstraksi kemudian dilakukan pengujian terrhadap baktei. Hasil pengujian aktivitas antibakteri menunjukkan bahwa dari konsentrasi rendah sampai konsentrasi tinggi diameter hambatan yang dihasilkan menunjukkan adanya aktifitas dapat menghambat bakteri streptococcus mutans. Daya hambat paling tinggi pada konsentrasi $6 \%$ yaitu $0,83 \mathrm{~mm}$ dan konsentrasi terendah pada konsentrasi $3 \%$ terhadap bakteri Streptococcus mutans.
\end{abstract}

\begin{abstract}
One of the plants that are often used as medicinal plants is Black Seed, Black Seed is a medicinal plant known in Indonesia by the name of black cumin. Black cumin seeds and essential oils (Nigella sativa L.) have been widely used in traditional medicine. Many studies have proven the effects of Nigella sativa extract. In various studies, black cumin seed oil shows efficacy as anti-cancer, anti-free radical and immunomodulator, analgesic, antimicrobial, anti-inflammatory, spasmolytic, bronchhodilator, hepatoprotective, and anti-hypertensive Advanced chemical analysis found that Black Seed contains carotene that is converted into vitamin A by heart. The purpose of this study was to determine the potential inhibition of methanol extract of black cumin seeds (Nigella Sativa L.) against Streptococcus Bkateri. This research uses a quantitative approach with an experimental method. This research was conducted in the Pharmacognition and Microbiology Laboratory of the Faculty of Health Sciences, Muhammadiyah University, Palangkaraya. The sample used was a sample of plant material, namely Black Cumin Seed (Nigella sativa $\mathrm{L}$ ) which had been dried and pollinated and then extracted and then tested against bactei. The results of testing the antibacterial activity showed that from low concentration to high concentration the diameter of the resulting inhibition showed that the activity could inhibit the bacteria streptococcus mutans. The highest inhibition at a concentration of $6 \%$ is $0.83 \mathrm{~mm}$ and the lowest concentration at a concentration of $3 \%$ against Streptococcus mutans.
\end{abstract}




\section{PENDAHULUAN}

Salah satu tumbuhan yang biasa digunakan masyarakat sebagai bahan obat adalah jintan hitam (Nigella sativa L.) yang secara empirik bermanfaat sebagai antioksidan, antidiabetes, antikolesterol, antikanker, antiinflamasi, antihistamin, antiinfeksi bakteri, virus dan parasit dan dapat digunakan sebagai immunomodulator (Setyawati, 200I: 2).

Salah satu tanaman yang sering dimanfaatkan sebagai tanaman obat adalah Habbatussauda, habbatussauda' merupakan tanaman obat yang dikenal di Indonesia dengan nama Jintan hitam. Biji dan minyak esensial jintan hitam (Nigella sativa L.) telah banyak digunakan dalam pengobatan tradisional. Banyak penelitian yang telah membuktikan efek ekstrak Nigella sativa. Dalam berbagai penelitian, minyak biji jintan hitam menunjukkan khasiat sebagai anti kanker, anti radikal bebas dan immunomodulator, analgesik, antimikroba, anti inflamasi, spasmolitik, bronkhodilator, hepatoprotektif, dan anti hipertensi Analisis kimia lanjutan menemukan bahwa habbatussaudaa mengandung karoten yang diubah menjadi vitamin $A$ oleh hati (Khasanah, 2009).

Karies gigi merupakan penyakit bakterial yang menyerang gigi dimana bagian dari organik dari gigi mengalami destruksi, sedangkan bagian dari anorganiknya mengalami dekalsifikasi. Karies gigi merupakan salah satu penyakit gigi dan mulut yang paling sering dijumpai dimasyarakat. Karbohidrat yang tertinggal dimulut, permukaan dan bentuk gigi serta mikroorganisme merupakan penyebab penyakit karies gigi.Dalam setiap $\mathrm{ml}$ air ludah dijumpai 10-200 juta bakteri. Jumlah maksimum bakteri-bakteri ini dijumpai pada pagi hari atau setelah makan. Salah satu mikroorganisme penting yang dijumpai dalam mulut adalah streptococcus mutans (Martina, 20I5).

Sesuai dengan Rencana Induk Riset LP2M UM PalangkarayaTahun 2019-2029 yang menjelaskan tentang permasalahan diindonesia di bidang Kesehatan dan Obat sangat terkait dengan pengembangan sediaan farmasi yaitu : (I) pengembangan bahan baku obat dari bahan alam (2) mutu produk dari hasil riset terbaru dan mutakhir sehingga produk dapat dipasarkan sesuai dengan standar yang berlaku di Indonesia.

Berdasarkan fakta diatas dilakukan penelitian mengenai efek jintan hitam terhadap bakteri rongga mulut. Penyakit pada rongga mulut dapat disebabkan oleh beberapa hal, antara lain mikroba dalam mulut. Streptococcus mutans adalah bakteri utama penyebab karies gigi yang merupakan penyakit multifaktoral dimana terjadi suatu kelainan pada rongga mulut.

\section{METODOLOGI}

Penelitian ini menggunakan pendekatan kuantitatif dengan metode ekperimental. Penelitian ini dilakukan di laboratorium Farmakognosi dan Mikrobiologi Fakultas IImu Kesehatan Universitas Muhammadiyah Palangkaraya.

Sampel yang digunakan pada penelitian ini adalah sampel dari bahan tanaman yaitu Biji Jintan Hitam (Nigella sativa L) yang telah dikeringkan dan diserbukkan. Sampel ditimbang sebanyak $500 \mathrm{~g}$, kemudian dimasukkan kedalam wadah maserasi dan ditambahkan pelarut metanol hingga terendam seluruhnya. Wadah maserasi ditutup rapat $1 \times 24$ jam disimpan ditempat yang tidak terkena sinar matahari langsung, selanjutnya dipisahkan antar amapas dan filtrat, ampas diekstraksi kembali dengan metanol selama $3 \times 24$ jam, ekstrak methanol yang diperoleh diangin- anginkan hingga didapatkan ekstrak kental metanol biji Jintan Hitam (Nigella sativa L).

Sebanyak $10 \mathrm{mg}$ ekstrak metanol biji jintan hitam (Nigella sativa $L$ ) dilarutkan dalam medium 0,2 $\mathrm{ml}$ DMSO dengan menggunakan mikropipet, kemudian dicampurkan dengan 9,8 ml medium Nutrient Agar hingga diperoleh volume $10 \mathrm{ml}$. campuran dituangkan ke dalam cawan petri secara aseptis dan digoyang- 
goyangkan agar merata dan dibiarkan memadat. Biakan mikroba uji digoreskna diatas medium kemudian diinkubasi pada suhu $37^{\circ} \mathrm{C}$ selama $1 \times 24$ jam. Dilakukan pengamatan aktivitas antimikroba dengan mengamati ada tidaknya pertumbuhan mikroba pada medium.

\section{HASIL DAN PEMBAHASAN}

Hasil penelitian yang telah dilakukan pada ekstrak metanol biji jintan hitam (Nigella Sativa L) terhadap bakteri Streptococcus mutans diperoleh hasil sebagai berikut:

Tabel I. Hasil pengamatan uji KHM ektrak metanol biji jintan hitam (Nigella Sativa L) terhadap bakteri Streptococcus mutans

\begin{tabular}{|c|c|c|c|c|c|}
\hline Mikroba Uji & \multicolumn{5}{|c|}{ Ektrak metanol biji jintan hitam } \\
\cline { 2 - 6 } & $3 \%$ & $4 \%$ & $5 \%$ & $6 \%$ & $7 \%$ \\
\hline Streptococcus mutans & - & - & - & - & - \\
& & & & & \\
\hline
\end{tabular}

Keterangan:

$+=$ Jernih

- $=$ Keruh

Tabel 2. Hasil pengamatan uji KBM ektrak methanol biji jintan hitam (Nigella Sativa L) terhadap bakteri Streptococcus mutans

\begin{tabular}{|c|c|c|c|c|c|}
\hline Mikroba Uji & \multicolumn{5}{|c|}{ Ektrak metanol biji jintan hitam } \\
\cline { 2 - 6 } & $3 \%$ & $4 \%$ & $5 \%$ & $6 \%$ & $7 \%$ \\
\hline Streptococcus mutans & + & + & + & + & + \\
& & & & & \\
\hline
\end{tabular}

Keterangan:

$+\quad=$ Bunuh

- $=$ Tidak Membunuh

Berdasarkan hasil uji skrining, pengujian KHM dilakukan dengan menggunakan bakteri uji Streptococcus mutans. Pada pengujian ini digunakan 5 konsentrasi sampel ekstrak biji jintan hitam yaitu 3\%, 4\%, 5\%, 6\% dan 7\% Hasil yang diperoleh pada uji KHM pada konsntrasi 3\% sampai 7\% sampel mampu menghambat pertumbuhan bakteri Streptococcus mutans.

Pengujian selanjutnya adalah yaitu uji KBM, hasil pengujian KBM yang didapatkan yang didapatkan 3\% sampai 7\% ekstrak terjadi pertumbuhan bakteri dengan adanya goresan yang timbul pada medium NA setelah diinkubasi selama $1 \times 24$ jam. Jadi pada konsentrasi terendah $3 \%$ yang mampu membunuh bakteri Streptococcus mutans.

Jadi, hasil yang diperoleh pada uji KHM dan KBM yaitu pada konsentrasi terendah 3 \% sampel yang mampu menghambat dan membunuh pertumbuhan bakteri Streptococcus mutans. Uji selanjutnya yaitu pengujian aktivitas antibakteri biji jintan hitam (Nigella sativa L) menggunakan metode difusi agar. Metode ini merupakan metode yang efektif dan efesien dalam menentukan besarnya diameter hambat suatu sampel pada bakteri uji sebanyak $20 \mu$ l dengan konsentrasi yang berbeda- beda (3\%, $4 \%, 5 \%, 6 \%$, dan $7 \%)$.

Tabel 3. Hasil diameter hambatan ektrak methanol biji jintan hitam (Nigella Sativa L) terhadap bakteri Streptococcus mutans

\begin{tabular}{|c|c|c|c|c|}
\hline \multirow{2}{*}{$\begin{array}{c}\text { Konsentrasi ektrak } \\
\text { methanol biji jintan } \\
\text { hitam }\end{array}$} & \multicolumn{2}{|c|}{ Diameter hambatan (mm) } & $\begin{array}{c}\text { Rata-rata Daya } \\
\text { Hambat mm }\end{array}$ \\
\cline { 2 - 4 } & I & II & III & \\
\hline $3 \%$ & 0,70 & 0,72 & 0,65 & 0,69 \\
\hline $4 \%$ & 0,83 & 0,85 & 0,80 & 0,82 \\
\hline $5 \%$ & 0,75 & 0,74 & 0,71 & 0,73 \\
\hline $6 \%$ & 0,84 & 0,86 & 0,79 & 0,83 \\
\hline $7 \%$ & 0,72 & 0,73 & 0,81 & 0,75 \\
\hline
\end{tabular}

Hasil pengujian aktivitas antibakteri menunjukkan bahwa konsentrasi yang digunakan dari konsentrasi rendah sampai konsentrasi tinggi diameter hambatan yang dihasilkan, yaitu menunjukkan adanya aktifitas dapat menghambat terhadap bakteri streptococcus mutans dari konsentrasi rendah hingga konsentrasi tinggi memberikan daya hambat paling tinggi pada konsentrasi $6 \%$ yaitu 0,83 $\mathrm{mm}$ dan konsentrasi terendah pada konsentrasi 3\% terhadap bakteri Streptococcus mutans.

\section{KESIMPULAN}


Berdasarkan hasil penelitian yang telah dilakukan dapat disimpulkan bahwa:

Ekstrak metanol biji jintan hitam (Nigella sativa L.) dapat menghambat dan membunuh pertumbuhan bakteri Streptococcus mutans mulai pada konsentrasi $3 \%$.

\section{REFERENSI}

I. Khasanah, Nur. 2009. "Pengaruh Pemberian Ekstrak Jintan Hitam (Nigella sativa L.) terhadap respon Proliferasi Limfosit Limpa Mencit balb/c yang diinfeksi Salmonella typhimurium". Semarang

2. Setyawati, Nur. 2010. Terapi Pengobatan dan Manfaat habbatussauda' (Jintan Hitam). Alqowam Publishing. Solo.

3. Martina, 20I5. Pengaruh Ekstrak Biji Jinta Hitam (Nigella sativa L.) Terhadap Adhesi Streptococcus mutans Pada Neutrofil. Jember 